\title{
Mainstreaming Regional Budget (APBD): Issues and Challenges in Riau Province in 2015
}

\author{
Alexsander Yandra Universitas Lancang Kuning, Indonesia \\ Sri Roserdevi Nasution Universitas Lancang Kuning, Indonesia \\ Harsini Universitas Lancang Kuning, Indonesia \\ Ismail Suardi Wekke Sekolah Tinggi Agama Islam Negeri (STAIN) Sorong, Indonesia
}

\begin{abstract}
This research explores issues related to mainstreaming the 2015 Regional Budget (Anggaran Penerimaan dan Belanja Daerah/APBD) of Riau Province amounted IDR 10.7 trillion. Based on the data obtained from the Riau Finance and Asset Management Board (Badan Pengelolaan Keuangan dan Aset Daerah/ BPKAD), Riau could only spend APBD 37.58\% of APBD until October 2015. Meanwhile, the Ministry of Home Affairs of the Republic of Indonesia calculated Riau spent only 59.6\% throughout 2015 and it wast the lowest regional spending in Indonesia. This poor expenditure rate demonstrates a problem in the implementation of Riau's APBD which was inneficient and not yet relevant. An assessment by government expenditure theory reveals that these problems indicate a gap in APBD allocation that affect on the non-performance regional development as targeted in mid-term regional development plan (RPJMD). This APBD seems to perform only a budget plan, not an implemented budget policy yet.
\end{abstract}

Keywords:

Government Expenditures; Policy Implementation; Indonesia

\section{INTRODUCTION}

As a portion of the development policy, the budget is a collection of public money and the public can use it through

Alexsander Yandra is a lecturer and researcher at Department of Government Universitas Lancang Kuning with focus on local politics. e-mail: alexsy@unilak.ac.id

Sri Roserdevi Nasution is a lecturer and researcher at Department of Government Universitas Lancang Kuning with focus on local politics

Harsini Harsini is a lecturer and researcher at Department of Government Universitas Lancang Kuning with focus on local politics

Ismail Suardi Wekke is a lecturer and researcher at Department of Government Sekolah Tinggi Agama Islam Negeri Sorong with focus on religion and multiculturalism.

Authors would like to thanks to Universitas Lancang Kuning and Ministry of research and higher education (Kemenristek DIKTI) for their support and funds to run the research. We also thank to Fitra Riau and Sekretaris Daerah Provinsi Riau for their cooperation and information. public documents (Baker, 2015). In fact, the budget as a public document (policy) is something that cannot be used by the public (Mangkoesoebroto, 2001). Based on an occurring preference, the budget is constructs by economists, accountants, public administration, and political budgetary policies are dominated by the executive and legislative (Thurmaier \& Willoughby, 2001). This shows that the process of preparation and budget planning, budget execution, to budget evaluation is still within the intervention by the government. 
The APBD is adjusted with the needs of government and the capability of regional income. The Regional Budget must observe the Regional Government Work Plan (Rencana Kerja Pemerintah Daerah/ RKPD) in order to realize the services to the community in achieving the State's goals. The Government Regulation No. 58/2005 on the Regional Financial Management in Chapter IV of the Formulation of the Regional Budget Plan,

"'The process of formulating Regional
Budget Plan shall be in accordance with
the Regional Medium-Term
Development (Rencana
Pembangunan Jangka Menengah
Daerah/RPJMD), RKPD, General Policy
of Regional Budget, Interim Budget
Priorities and Ceilings (Prioritas Plafon
Anggaran Sementara/PPAS) and Work
and Budget Planning of Regional Work
Unit (Rencana Kerja Anggaran Satuan
Kerja Perangkat/RKA-SKPD)". - Article
29 to Article 42.

The regulation appears to be a guideline in the regional budget management in Riau Province in 2015 specifying the design of the regional budget which amounted to Rp10,7 trillion. Riau
Province Government and the Regional House of People's Representative (DPRD) approved such plan to serve as Regional Regulation No. 4/2014 and Governor Regulation No. 27/2014 on the 2015 Regional Budget as a reference for the government work unit for the purpose of use of the regional finance (Riau Province Post, 5 September 2015).

However, the main allocation of 2015 Regional Budget allocation had led into a gap in its spending. The Office for Management of Regional Finance and Assets (Badan Pengelola Keuangan dan Aset Daerah/BPK RIAD) data showed that the realization of the 2015 Regional Budget of Riau Province had only recorded $37.58 \%$ portion of allocation until October 2015. The Government considered that Riau Province as poor in term of allocating 2015 Regional Budget. Until the $30^{\text {th }}$ July 2015, realization of Riau Province's 2015 Regional Budget was the fourth lowest in Indonesia ${ }^{1}$. Furthermore, the Ministry of Home Affairs of the Republic of Indonesia noted that the calculation of the realization of Regional Budget spending of Riau Province for period January-December 2015 was the lowest in Indonesia as it recorded $59,6 \%$ portion of allocation and

\footnotetext{
${ }^{1}$ Interview with Assistant II Regional Secretariat of Riau Province, Masperi.
} 
became five provinces in the lowest budget allocation rank. The issues of 2015 Regional Budget of Riau Province were appealing to study and to examine by doing a comprehensive and deep research in order to find the pattern of main allocation of financial governance that tends to be influenced by political conditions.

This research refers to the research of public policy implementation which previously had been conducted with the topic of the constraints of Public Policy implementation of the Regional Regulation No. 2/2005 on the transparency and participation. The issues were comparable to the implementation of Riau Province's 2015 Regional Budget, where policies made by the government were not relevant to the public needs, consequently, Riau Province's 2015 Regional Budget had led into a gap in term of its spending.

The analysis engaged was the grand theory of the approach of regional spending concept describing about the spending standardisation (Kuncoro, 2014). The theory of basic principles of government budget management by (Musgrave, 1959) is also used as an instrument for identifying the function of Riau Province local budget allocation in 2015 from the authoritative function, distribution function and the stability function (Thurmaier \& Willoughby, 2001). Several budget financial policies are being analysed through the concept of public policy discretion as (Nugroho, 2008; Suparman, 2017) delivered. This approach is used because in an era of democratization and decentralization, the budget is required to be placed in the correct understanding of local budget as a tool to promote the interests of justice, development, the poor, and other marginalized groups (Alm, Aten, \& Bahl, 2001; Dixon \& Hakim, 2009; Silver, 2005).

\section{THEORETICAL PERSPECTIVES \\ Research Method}

The methodology used in this research was a phenomenological descriptive qualitative (Sugiyono, 2005). While BPK RIAD, the Regional Development Planning Agency (Badan

Perencanaan

Daerah/Bappeda) and Regional Budget Agency of Regional House of People's Representative (DPRD) served as the analysis units. This study employs observation technique with the pattern of investigation, in-depth interviews, and documentation. The obtained data information was compared through focus group discussions with the Forum 
Table 1. The Budget gap from the side of revenue and spending of Regional Budget in Riau Province for the year period of 2011 up to 2015

\begin{tabular}{|c|c|c|c|c|c|c|c|c|c|c|c|c|}
\hline \multirow{2}{*}{ Tahun } & \multicolumn{2}{|c|}{ Total Revenue (Miliar) } & \multicolumn{2}{|c|}{$\begin{array}{l}\text { Total Expenditure } \\
\text { (Miliar) }\end{array}$} & \multicolumn{2}{|c|}{$\begin{array}{l}\text { Surplus/Defisit } \\
\text { (Miliar) }\end{array}$} & \multirow{2}{*}{$\begin{array}{c}\text { Variance } \\
\text { Surplus/Defisit } \\
\text { (Miliar) }\end{array}$} & \multirow{2}{*}{$\%$} & \multirow{2}{*}{$\begin{array}{c}\text { Variance } \\
\text { Revenue } \\
\text { Surplus/Defisit } \\
\text { (Miliar) }\end{array}$} & \multirow{2}{*}{$\%$} & \multirow{2}{*}{\begin{tabular}{|c|} 
Variance \\
Expenditure \\
Surplus/Defisit \\
(Miliar)
\end{tabular}} & \multirow{2}{*}{$\%$} \\
\hline & OB & $A B$ & $\mathrm{OB}$ & $A B$ & OB & $A B$ & & & & & & \\
\hline 2011 & $4.625,00$ & $5.440,00$ & $4.798,00$ & $4.265,00$ & $-173,00$ & $1.175,00$ & $-1.348,00$ & $-679,19$ & 815,00 & 117,62 & $-533,00$ & 88,89 \\
\hline 2012 & $5.488,00$ & $6.847,00$ & $6.367,00$ & $8.737,00$ & $-879,00$ & $-1.890,00$ & $1.011,00$ & 215,02 & $1.359,00$ & 124,76 & $2.370,00$ & 137,22 \\
\hline 2013 & $6.938,00$ & $6.995,00$ & $8.915,00$ & $7.525,00$ & $-1.977,00$ & $-530,00$ & $-1.447,00$ & 26,81 & 57,00 & 100,82 & $-1.390,00$ & 84,41 \\
\hline 2014 & $7.127,00$ & $8.132,00$ & $8.277,00$ & $5.602,00$ & $-1.150,00$ & $2.530,00$ & $-3.680,00$ & $-220,00$ & $1.005,00$ & 114,10 & $-2.675,00$ & 67,68 \\
\hline 2015 & $7.407,00$ & $6.911,00$ & $11.388,00$ & $7.761,00$ & $-3.981,00$ & $-850,00$ & $-3.131,00$ & 21,35 & $-496,00$ & 93,30 & $-3.627,00$ & 68,15 \\
\hline
\end{tabular}

Indonesia untuk Transparansi Anggaran (Fitra Riau Province) in August 2017 (Yandra, 2012). Then, a qualitative interpretation was used both in the native point of view and ethical way. The interpretation in the way of native point of view is an interpretation of data from the issues of research subject towards its environment and surrounding. While the ethical interpretation was interpreted according to the view of the researcher as based on the relevant literature study (Moleong, 2002).

The budget as a policy instrument is something essential in achieving development and prosperity. Ideally speaking, in each budget formulation, citizens are allowed to have the opportunity to participate in the budget process. However, the budget problem in 2015 is completely revealing the absence of public involvement in the budget process. The Riau Province budget is still dominated by the executive and legislative roles, as if the budget is a technocratic product that works only for certain groups interest. The Riau Province budget is showing a big gap budget from year to year, the budget tends to be used for short-term interests, so the implication that affects the fiscal strength is that it declines from year to year (See: Table 1).

\section{Politics of Budgeting}

Politics of Budgeting has several definitions (Rubin, 2016; Wildavsky, 1968; 1997). First, Budget politics is the setting of various policies on the budget process that includes questions on how the government finances its activities; how public money is earned, managed and distributed; who benefits and loses; what opportunities are available both for negative deviations and for improving public services. Second, Budgetary politics is a process of mutual influence among various stakeholders in determining the scale of development priorities due to the 
limited available public funding sources. importantly is meeting the needs of Third, Budgetary politics is the process of conflicting communities through a process influencing budget allocation policy that is of compromise in the political process. done by various parties with an interest in Thus, the meaning of local budget politics the budget. Fourth, Budget politics is the in this study is the policy (local political process of asserting power or political choices) to allocate and distribute the power between the various parties involved budget (Nurcholish, 2005; Olken, 2010) in the determination of policy and budget Or in this case is a policy of local allocation (Colombatto, 2001).

In Indonesian political context, the APBD is a political document of agreement between the legislature (DPRD) and the executive (Blöndal, Hawkesworth, \& Choi, 2009; Sjahrir et.al., 2013). APBD is a form of commitment from the executive to the legislator, which is also used to determine the priorities and financial needs. In the public sector, the budget is a political document embodied in the executive's commitment and the legislative agreement on the use of public funds for a particular interest.

The budget is not just a technical problem, but rather a political tool (political tool). Because budgets are not based on technical provisions or through economic calculations alone, but more than that the budget is drafted by an agreement, and is government to allocate and distribute the budget in APBD in order to realize a certain goal that has been determined.

\section{CONTEXT: FINDINGS AND DISCUSSION} Gap in the Allocation of Regional Budget of Riau Province

When the data from previous years were reviewed by comparing the income and expenses of the Government of Riau Province from the year 2011-2015, it was likely to overestimate (over predicting) expenses but underestimate (disparate) income. This means that there was a budget imbalance or gap seen from the comparison of a high income to low expenses (Akbar, Pilcher, \& Perrin, 2012). Such pattern had become the main allocation of Riau Province's 2015 Regional Budget affecting the credible a translation of the vision and mission of the elected regional head.

Budgeting goes beyond just scarce resources between activities, but more 
Picture 1. Graph of Regional Income for the year period of 2014-2017

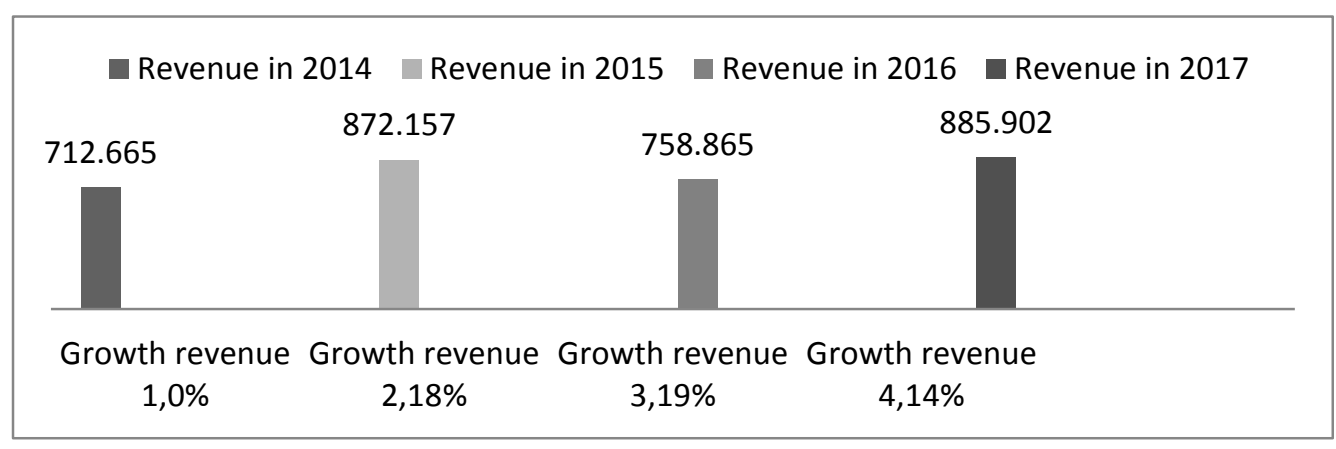

Sources: Analysed from APBD Riau Province 2014-2017.

performance of the Government of Riau from the Regional Budget data of Riau Province before the public, due to its Province, an occurring variance tended to welfare growth and development were far away from the community's expectation. In addition, the Riau Province's Regional Budget spending showed an ineffective trend due to the usage orientation of work — program based—-the budget which was difficult to achieve in a year.

From the table above, it can be observed that the government in Riau Province tended to systematically conduct a positive variance in its revenue side and negative variance in its spending. Although such systematic positive or negative variances can be caused by many factors (Mayper, Granof, \& Giroux, 1991), it 1

indicates a gap between the budget. Positive variance in the income side indicates the regional tendency to specify an easy to achieve targets. Negative variance in the spending side indicates the tendency to specify the difficult to achieve and to realize targets. This study reveals be larger or smaller, which means the higher the income, the lower the spending were (See: Picture 1).

The condition reflects that the consistency of the Riau Province Government in realizing 2015 Regional Budget was still considered very poor (FITRA Riau Province, 2015). Seen from the regional income from the year period of 2014-2017, a regional income of Riau Province had been relatively fluctuating in sound condition and had no disruption towards the economic and development growth, such condition is shown by Picture

The graph displays that Riau Province's income tended to be very stable with the year-to-year increasing income growth (2014-2017). The income growth provides an analysis that the Riau Province's communities still have high awareness in paying taxes and a good level 
of compliance of the communities as supported with relatively good regional government's endeavor to optimize the potential income from tax and non-tax sectors. On the contrary, if reviewed from Riau Province's regional expenditure from year to year (2014-2017), this variable also shows a steadily increasing.

Regional Expenditure as shown by the above graphic displays that the yearly increasing growth of regional expenditures, this means that the regional expenditures of Riau Province Government had increased every year, the regional expenditures may take the form of capital expenditures and even goods and services expenditures. From the data in 2015 with the realization of $A P B D$ of $68,1 \%$, the Government of Riau Province use more APBD expenditure for capital expenditure with percentage $59,76 \%$ while goods and service expenditure 6,19\% (Fitra Riau Province 2017).

Capital expenditures represent expenditures made in term of capital formation in order to increase fixed assets or other assets that provide more benefits, such as spending for maintenance costs that aim to maintain or increase the useful life, increase the capacity and quality of assets. The 2015 Capital Expenditures were highly intended for the rehabilitation of buildings, the provision of facilities, consulting services, experts and most of the expenditures were allocated for the procedural budget allocation, there was no breakthrough for the development of public facilities.

\section{Main Allocation in the Implementation of Regional Budget of Riau Province}

The table 2 shows the expenditures realization of 2015 Regional Budget of Riau Province after the audit by Audit Board of Indonesia (Badan Pemeriksa Keuangan/BPK RI). The table above also indicates that the Riau Province's Initial Regional Budget for the year of 2015 amounted to 10.7 Trillion, while its Revised Regional Budget was 11.3 Trillion with its budget realization reached 7.7 Trillion or $68 \%$ portions. Seen from the realization data of Riau Province's 2015 Regional Budget, most of $82 \%$ portions were allocated for employee expenditures, $86 \%$ for profit sharing expenditures and $102 \%$ were for the grant, compared to its targeted allocation (Development, Infrastructure, Health, and Education). While the lowest absorption was found in $35 \%$ of financial aid expenditure, $32 \%$ of social assistance expenditure and $0 \%$ of unexpected expenditure. From the total absorption of 2015 Regional Budget, it 
Table 2. Realization of Capital Expenditures in 2015 (through an Auction at LPSE)

\begin{tabular}{|c|l|r|r|c|}
\hline No. & \multicolumn{1}{|c|}{ SKPD } & \multicolumn{1}{c|}{ Allocation } & Capital Expenditure & Percentage \\
\hline 1 & $\begin{array}{l}\text { Bina Marga } \\
\text { Authorities }\end{array}$ & $2,184,714,247,000.00$ & $1,490,773,677,716.56$ & $68 \%$ \\
\hline 2 & $\begin{array}{l}\text { Arifin Ahmad } \\
\text { Centre Hospital }\end{array}$ & $150,889,831,999.00$ & $123,275,340,181.00$ & $82 \%$ \\
\hline 3 & $\begin{array}{l}\text { Cipta Karya } \\
\text { Authorities }\end{array}$ & $139,446,004,500.00$ & $74,747,359,000.00$ & $54 \%$ \\
\hline 4 & $\begin{array}{l}\text { Education } \\
\text { Authorities }\end{array}$ & $78,856,295,450.00$ & $13,661,838,180.00$ & $17 \%$ \\
\hline 5 & DPRD Secretariat & $16,721,953,800.00$ & $6,187,411,900.00$ & $37 \%$ \\
\hline 6 & Income Authorities & $10,202,519,965.00$ & $4,361,292,800.00$ & $43 \%$ \\
\hline 7 & $\begin{array}{l}\text { BKD of Riau } \\
\text { Province }\end{array}$ & $8,998,374,350.00$ & $2,769,470,000.00$ & $31 \%$ \\
\hline 8 & Farms Authorities & $26,806,150,069.00$ & $2,707,075,000.00$ & $10 \%$ \\
\hline 9 & $\begin{array}{l}\text { Government } \\
\text { tourism Office }\end{array}$ & $6,459,645,640.00$ & $2,608,325,500.00$ & $40 \%$ \\
\hline 10 & $\begin{array}{l}\text { Department of } \\
\text { Transportation }\end{array}$ & $17,741,235,000.00$ & $2,304,247,000.00$ & $13 \%$ \\
\hline 11 & Labor offices & $2,756,971,000.00$ & $2,230,813,500.00$ & $81 \%$ \\
\hline 12 & $\begin{array}{l}\text { Tampan } \\
\text { Psychiatric } \\
\text { Hospital }\end{array}$ & $5,823,427,493.00$ & $1,474,221,900.00$ & $25 \%$ \\
\hline
\end{tabular}

Sources: Analysed from APBD Riau Province 2014-2017.

recorded $59.76 \%$ portions of capital goods and service expenditures. It may expenditures and $6.19 \%$ portions of goods also be caused by the transition of and services expenditures. In the last four Governor from Anas Maamun to Acting years (2014-2017) there is a trend that Governor, Arsyad Juliandi, who could not the decisions taken by the regional optimally manage the use of budget.

government in the implementation of Regional Budget were less effective when compared to the increase in Regional- Own Source Revenue (Penerimaan Anggaran Daerah/PAD) and budget realization (See table 2).

This data reveals that its realization is reaching $68.1 \%$, with $59.76 \%$ budget absorptions were dominated by capital expenditures. Capital expenditures were highly allocated to maintain pre-existing assets, this had been proved that in 2015, Riau Province Government minimized its
Subsequently, the Acting Riau Province Governor served as Head of Regional Government of Riau Province. However, Acting Riau Province Governor has limitations in carrying out the regional governmental affairs. As mentioned in Government Regulation No. 49/2008;

"The regional head or the acting regional head as referred to in Article 130 clause (1) and (3), and Article 131 clause (4), or whom appointed to fill the vacancy of the position of the regional head upon its 
resignation in order to nominate/be nominated as candidate for regional head/deputy regional head, as well as the regional head appointed from the deputy regional head in order to replace the resigning regional head to nominate/be nominated as candidates for regional head/deputy regional head shall be prohibited from: a) transferring an officer, b) revoking a license previously issued by the official and/or issuing permits that are on contrary to those issued by the previous official, c) making a policy on regional expansion which is in contrary to the policy of the previous official and d) making policy which is in contrary to the policy of the governance and development programs of previous official". - Article 132A, Paragraf 1.

Furthermore, in clause (2), "The provisions referred to in clause (1) may be exempted after obtaining written approval from the Minister of Home Affairs". Thus, based on the regulation of Law No. 32/2004 and Residential Regulation No. $49 / 2008$, it is clear that the authority of Acting Regional Head or Substitute Regional Head is very limited compared to the authority of the Elected Regional Head. This resulted in the low realization of Regional Budget of Riau Province in 2015 as Acting Governor had no authority to take an action in accelerating the budget realization, Acting Governor can only organize governmental matters and predetermined development programs.

Based on these conditions, the priority taken by Acting Governor in the Regional Budget allocation was highly intended for non-consumable equipment. Below is the realization of a sector-based capital expenditures in 2015 included in the auction at the Electronic Procurement Service (Layanan Pengadaan Secara Elektronik/LPSE).

The table 2 provides information that the use of Riau Province's 2015 Regional Budget for capital expenditure, of which $82 \%$ was highly allocated for Arifin Ahmad Hospital, while $81 \%$ was in Labor Offices. Furthermore, the lowest capital expenditure was at the Farms Authorities of $10 \%$ and Department of Transportation of $13 \%$. Based on the analysis conducted with the secretary of Forum Indonesia Transparansi Anggaran (FITRA) Riau Province,

"The government's tendency to allocate greater capital expenditure as it deals with the interests of the community, such as for the infrastructure development and non-consumable equipment. While the expenditures for 
consumable goods and service is done within one fiscal year and it is highly manipulated by fraud, such goods price mark-up." - Interview with Tarmizi, FITRA, August 4, 2017.

This reflects that the use of 2015 Regional Budget of Riau Province for capital expenditure was considerably allocated for infrastructure development and non-consumable equipment (Susanti \& Budidarsono, 2014). Therefore, this option was a procedural effort of government tasks, especially financial policies in 2015, in order to avoid financial fraudulence in order to observe ethical standards. This form was another prevention effort so that mark-up practices did not happen again. This appeared in post-arrest of Anas Maamun Governor as he was red-handed for corruption case over land conversion in Kuantan Sengingi Regency in July 2015 by Corruption Eradication Commission (Komisi Pemberantasan Korupsi/KPK). It affected the acting governor's concern in the allocation of Regional Budget. It was even alleged that 2015 Regional Budget of Riau Province was dominated by the project interests of particular groups (FITRA Riau Province, 2015).
On the contrary, the government's unwillingness to take risks on the use of the budget was an indication of low political will by the acting Governor, since there was no direct guidance since 2015 for Regional Budget in the acceleration of economic development and other physical development. Regional Budget tended to be used as an instrument for elite's group in the government to realize its political mission, consequently, Regional Budget as a central part of the realization of community welfare was slow in its progress while its implementation was adjusted to the elites. Implementation dilemma of various policies was also caused by policy makers and policy implementers who had their own different strategies.

It was even apparent from the implementation of Riau Province's Regional Budget, government strategy had a tendency to retain the budget because from the beginning of Regional Budget Arrangement there was no covenant between the executive and legislative on the direction and general policy (Dana Alokasi Umum/DAU) and budget priorities, which would serve as guidelines for the budget arrangement. Executives drafted its Regional Budget in accordance with AKU and budget priorities, which was then 
submitted to the legislative to be studied and discussed together before being established as a regional regulation (Abdullah, 2004).

Riau Province has high Regional OwnSource revenue (Pendapatan Asli Daerah/PAD), but it is not supported by the capability of regional government in realizing it in accordance with the target and public expectation (Riau Province's communities). The low absorption of 2015 Regional Budget which had been stipulated in the Regional Regulation No. 4/2014 and Governor Regulation No. 27/2014 on 2015 Regional Budget, demonstrates that Riau Province Government had not observed the regulation they had made by agreement with DPRD. Therefore, Riau Province's 2015 Regional Budget can be considered less optimal in term of its use of financial budget. Even the level of relevance was far from the target when viewed from the infrastructure development program, as some of the financial expenditures were used for employee spending. According to Thurmaier and Willoughby, the authority for the use of Regional Budget tended to the regional leader as Riau Province's 2015 Regional Budget has raised an issues of budget autocracy relying on the disposition of regional leader (Thurmaier \&
Willoughby, 2001). Some findings indicated that the constraint preferences in the implementation of 2015 Regional Budget of Riau Province which realization had transition of the regional leader (acting governor), as well as the rotation conditions in the government bureaucracy. The reality described that, political consolidation by the government elites seemed to be slow, this condition was interpreted to interfere Riau Province's 2015 Regional Budget Allocation.

\section{Usage Trend of Riau Province's 2015} Regional Budget

An interesting phenomenon in the recent financial management of Riau Province region, namely, the frequent occurrence of budgetary rest (Sisa Lebih Pembiayaan Anggaran/Silpa) in the Report on Budget Realization (LRA). Seen from the last three years, it shows the trend of Silpa, there was a decline as shown below. The graphic above shows a decreased Silpa from the use of budget, but this trend 


\section{Table 3. Audit Results by Audit Board of Indonesia (BPK RI) towards Regional Budget of Riau Province in 2015}

\begin{tabular}{|c|c|}
\hline No & Audit Results \\
\hline 1 & $\begin{array}{l}\text { There were excess payments of Rp. } 306.880 .000 \text { and the inaccuracy of execution team } \\
\text { for the implementation of routine duties and functions of Rp. } 1.391 .510 .000 \text { within the } \\
\text { Government of Riau Province }\end{array}$ \\
\hline 2 & $\begin{array}{l}\text { Payments to Government Administration Assistant and people's welfare and General } \\
\text { Administration Assistant in Execution Team during the Service Period as Regent were Rp. } \\
85.510 .000 \text { not in accordance with the provisions. }\end{array}$ \\
\hline 3 & $\begin{array}{l}\text { xpenditure realization on the payment of patient's meals for FY of } 2014 \text { which amounted } \\
\text { Rp. 82.745.332 resulting in an excess Regional Budget of Riau Province in } 2015\end{array}$ \\
\hline 4 & $\begin{array}{l}\text { surance premium payments of buildings and libraries and, over the spending of the } \\
\text { gional budget by offices amounted to at least Rp. } 29.627 .714\end{array}$ \\
\hline 5 & $\begin{array}{l}\text { enditures realization of routine maintenance/periodic maintenance of the official car } \\
\text { tine/periodic maintenance of the Operational Office vehicles was not supported by } \\
\text { e evidence of its implementation }\end{array}$ \\
\hline 6 & $\begin{array}{l}\text { mounted to Rp. } 25.870 .000 \text { on procurement of book for SMA and SMK } \\
\text { um procurement of } 29 \text { units were not supported by a licensed computer } \\
\text { n }\end{array}$ \\
\hline 7 & to third parties communities did not fully comply with the provision of \\
\hline 8 & $\begin{array}{l}\text { ayment of capital expenditure on procurement of surveillance cameras (CCTV) at } \\
\text { of Management of Regional Finance and Assets amounted to Rp. 25.857.000 } \\
\text { rocurement results had not been utilized }\end{array}$ \\
\hline 9 & $\begin{array}{l}\text { Surety Bond amounted to Rp. } \\
\text { secretariat of DPRD and Health }\end{array}$ \\
\hline 10 & $\begin{array}{l}\text { surgery hospital Arifin Achmad } \\
00\end{array}$ \\
\hline 11 & ivities for FY of 2015 at Office of Highways \\
\hline 12 & $\begin{array}{l}\text { penditure for road lifting in Bagan Siapiapi- } \\
30.918 .369\end{array}$ \\
\hline 13 & $\begin{array}{l}\text { of the work package of the road construction of Teluk Piyai (Kubu) - Sei } \\
\text { Rp. } 1.406 .470 .000\end{array}$ \\
\hline 14 & $\begin{array}{l}\text { Delayed submission of Remaining Balance of Inventory Cash amounted to Rp. } \\
5.254 .540 .296\end{array}$ \\
\hline 15 & tlement of four types of receivables amounted to Rp. 1.347.373.855 \\
\hline 16 & $\begin{array}{l}\text { ther permanent investment management in the form of Capital Strengthening Fund (DPM) } \\
\text { for the development of Fish Cultivation at the Office of Fisheries and Marine did not comply } \\
\text { with the provisions }\end{array}$ \\
\hline 17 & $\begin{array}{l}\text { rmanent investment management in the form of Pola Swamitra Bukopin } \\
\text { ve at the Office of Cooperatives and Micro. Small and Medium Enterprises (SMEs) }\end{array}$ \\
\hline
\end{tabular}

Source: Audit Board of Indonesia in Riau Province.

did not support the positive use of budget instead of negative use. Seen from the programmes that were ineffectively implemented, as well as the results of the Compliance Audit towards the Provisions of Prevailing Law and Regulation related to the use of Riau Province's 2015 Regional Budget, there were 17 findings by BPK RI$\mathrm{RI}$ as follows. 
Based on the results of BPK RI examination of 2015 Regional Budget of Riau Province in the table above, it can be concluded that the gap in the use of budget was caused by the lack of control (lack control) in budget allocation. Supervision should be done from budget planning to budget allocation in order to minimize the budget fraudulence. Furthermore, Regional Budget allocation for capital expenditure in the need of stipend payment, routine or periodic maintenance cost and investment management was considered to overburden the Regional Budget (See: Table 3).

Based on the results of BPK RI examination of 2015 Regional Budget of Riau Province in the table above, it is conclusive that the gap in the use of budget was caused by the lack of control (lack control) in budget allocation. Supervision should be done from budget planning until budget allocation in order to minimize the budget fraudulence. Furthermore, Regional Budget allocation for capital expenditure in the need of payment of stipend, routine or periodic maintenance cost and investment management was considered to overburden the Regional Budget.

\section{Discretionary budget policy Riau Province}

The amount of fiscal space available in the budget is Rp10.7 trillion in 2015, should make the government be more flexible towards the regional development. Nevertheless, the statement did not match the expectations desired by the community, as the facts show the fiscal strength of Riau Province in the last four years (2014-2017) continues to decrease despite revenue annually sector increased (Figure 1). As the figure 1 shows the decreasing fiscal strength from year to year which allegedly occurred because fiscal discretion, this condition becomes problematic in budget policy in Riau Province 2015 (FITRA Riau Province, 2015).

Riau Province budget in 2015 did not have synergy between the high incomes with low expenditure. On one side, when viewed from the budget effeciency with a declining trend Silpa is considered as something positive but then it is having opposite impact to the fiscal strength that tends to decrease (negative) as the graph above exposes. A safe regional financial planning is, if the budget deficit can be closed with net, but the using of Silpa until doesn't remain one rupiah makes the financial planning looks fake, so it is doubtful accountability and honesty. 


\section{Scheme 1. Policy discretion schemes}

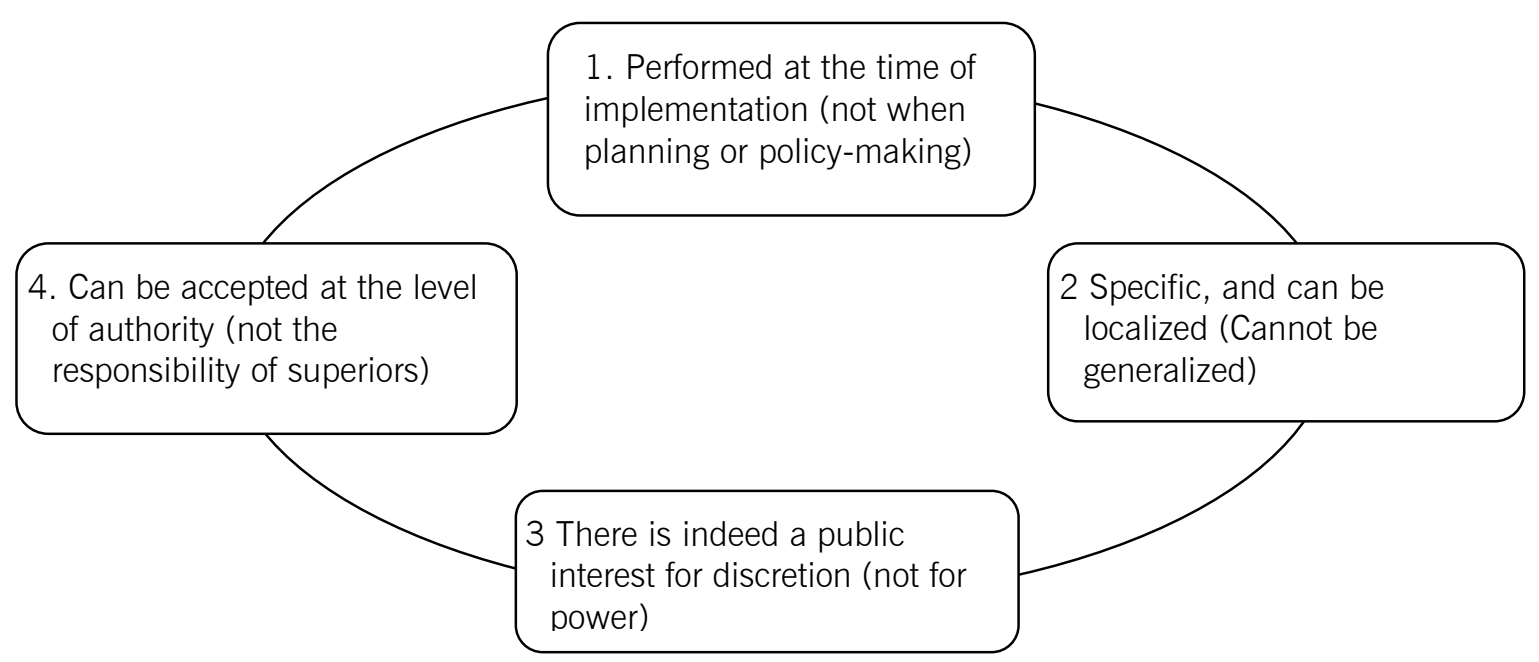

Sources: Syntesis from Taylor (1993); McCallum (1993) also Barro and Gordon (1983).

The condition happens because the condition that happens is case by case and discretion of financial policy conducted by in terms of public interest. Because the Riau Province government in the span discretionary decisions or actions of the year (2014 until 2017). The policy associated with the selected or designated discretion option is the government's by government officials to address more actions in keeping the budget, but it concrete problems encountered in happens in the projection of income. In governance in terms of legislation is not projecting revenue, the revenue trend of giving the option, regulation, incomplete or APBD Riau Province from 2014 to 2017 unclear. As the following frame is conveyed is basically improved but not balanced with by (Nugroho, 2008) on the principle of the achievements resulting from the discretionary public policy (See: Scheme budget. This means that the Government 1).

of Riau Province is still not maximizing in

Judging from the Scheme 1 , determining the projection of regional preference discretionary fiscal policy income in an effort to support sustainable budget Riau Province had been caused by development, because the future instability political factor after the suspect projection is lowered from the actual Governor Anas Maamun corruption, which potential (mark down). has effect for the poor performance of the

From the policy perspectives, bureaucracy that happen because the discretionary public policy (monetary rotational leadership was happening two policy) could or should be done if the times in bureaucratic organizations that 
triggered the realization of the budget be regressed. The next phase was the adaptation and synchronization program which also was slow because of the classic problem that cannot be avoided (Grillos, 2017). As the change of leadership in public administration institutions (bureaucracy) is still held hostage by political interests, these interests do not have uptake progress of the budget but rather slow down the progress of the budget. The reason for it is because the Riau Province budget 2015 is a political agreement and a consensus between the non-active governor and the bureaucracy leaders whom are also afraid to be dragged in the corruption case.

The reality of Riau Province APBD can be interpreted that the case with the local fiscal policy discretion is not linear in the development orientation purposes, instead, the discretionary fiscal policy is more focused on public money to rescue the budget that was allegedly not in accordance with the orientation of medium and long term regional development. Like the use of local money if for the payment of fees, insurance premiums of buildings and structures, political assistance grants, investment management that is assessed to burden the budget. In 2015, Riau Province provincial budget is used for more bureaucratic purposes even the greatest uptake in the interests is the bureaucracy, the bureaucracy even more spending than produce that is hindering economic growth.

Judging from the document analysis of Riau Province APBD, the consistency element in revenue and expenditure, the relevance of the program with the Regional Development Draft and effective use of the budget to the public interest. The relationship between the document has not made budget as government's main principal to carry out all the obligations, promises and policies into concrete plans and integrated in terms of what actions will be taken for the long term, what results will be achieved, what cost and who will pay the fee (Dobell \& Ulrich, 2002).

When discretionary fiscal policy budget is geared towards the interests of power in order not to be dragged to the various cases of corruption, the budget disparities policy is not to the people. Furthermore, Riau Province budget accountability is the responsibility of superiors not on the authority, the implications programs in the unit or unit level is not relevant in regional organizations. Somehow, discretionary policy continuously to happen like this, then the use of the budget is not done in 
the initial planning process. Budgeting is still a procedural way to use public money, however, it does not automatically mean its utilization is a reflection of the public needs and interests. Therefore, the budget efforts need to be done in a comprehensive and not partial manner. Thus, the budget reform is not simply to make better budget, but it is more important on the political dimension of the budget that includes the function of the budget, especially the distribution and allocation. The concept of budget democratization by involving the public in planning seems not followed by the elite commitment in fighting the collusions in planning the budgeting.

Another model that needs to be pursued in mainstreaming implementation of the budget is the concept of budget justice. Several issues in budget realization that needs solutions are; even, fair and controlled distribution so it will cope with the economic, development, and educating the society. In the future, the government needs to provide comprehensive information and accountable budgeting about innovative efforts so the concept of budget can be executed fair for every people in Riau Province.

\section{CONCLUSION}

The reports by BPK RI exposes the inconsistency of the Riau Province Provincial Government in realizing the 2015 APBD that is still considered to be a poor performance. The transition of elected Governor to Acting Governor in Riau Province in 2015 caused a limited authority to use the budget. Furthermore, during 2014-2016, Regional Budget had increased but did not have a positive impact as it can be seen from 17 findings generated by BPK RI. On the contrary, the facts show that Riau Province's fiscal power in the last four years (2014-2017) continues to decline even though the Regional Own- Source Revenue sector increases every year, it affected the discretion in fiscal policy in Riau Province by 2015 .

\section{REFERENCES}

Abdullah, S. (2004). Perilaku Oportunistik Legislatif dalam Penganggaran Daerah: Pendekatan Principal-Agent Theory. In Makalah Disajikan Pada Seminar Antarbangsa Di Universitas Bengkulu, Bengkulu, 4-5.

Akbar, R., Pilcher, R., \& Perrin, B. (2012). Performance Measurement in Indonesia: The Case of Local Government. Pacific Accounting Review, 24(3), 262-291. 
Alm, J., Aten, R. H., \& Bahl, R. (2001). Can Indonesia Decentralise Successfully? Plans, Problems and Prospects. Bulletin of Indonesian Economic Studies, 37(1), 83-102.

Baker, J. (2015). The Rhizome State: Democratizing Indonesia's Off-Budget Economy. Critical Asian Studies, 47(2), 309-336.

Barro, R. J., \& Gordon, D. B. (1983). Rules, discretion and reputation in a model of monetary policy. Journal of monetary economics, 12(1), 101121.

Blöndal, J. R., Hawkesworth, I., \& Choi, H.-D. (2009). Budgeting in Indonesia. OECD Journal on Budgeting, 9(2), 49.

Colombatto, E. (2001). Discretionary Power, Rent-Seeking and Corruption. ICER-International Centre for Economic Research, 24.

Dobell, P., \& Ulrich, M. (2002). Parliament's Performance in the Budget Process: A Case Study. Institute for Research on Public Policy.

Grillos, T. (2017). Participatory Budgeting and the Poor: Tracing Bias in a MultiStaged Process in Solo, Indonesia. World Development, 96, 343-358. Kuncoro, H. (2014). The Economic
Impacts of Government Spending Cut: The Case of Indonesia. Journal of Advanced Research in Law and Economics, 5(2), 120-135.

Mangkoesoebroto, G. (2001). Ekonomi Publik. BPFE, Yogyakarta.

Mayper, A. G., Granof, M., \& Giroux, G. (1991). An Analysis of Municipal Budget Variances. Accounting, Auditing \& Accountability Journal, 4(1), 29-50.

McCallum, B. T. (1993, December). Discretion versus policy rules in practice: two critical points: A comment. In Carnegie-Rochester Conference Series on Public Policy (Vol. 39, pp. 215-220). NorthHolland.

Moleong, J. L. (2002). Metodologi Penelitian Kualitatif. Remadja Karya. Musgrave, R. A. (1959). Theory of Public Finance: A Study in Public Economy. Nugroho, R. (2008). Public Policy. Jakarta: Elex Media Komputindo.

Nurcholish, H. (2005). Teori dan Praktik Pemerintahan dan Otonomi Daerah. Gramedia Widiasarana Indonesia.

Rubin, I. S. (2016). The Politics of Public Budgeting: Getting and Spending, Borrowing and Balancing. CQ Press. Sugiyono. (2005). Memahami Penelitian Kualitatif. Bandung: Alfabeta. 
Susanti, A., \& Budidarsono, S. (2014).

Land Governance and Oil Palm

Development: Examples from Riau

Province, Indonesia. The Global Land

Grab: Beyond the Hype. Zed Books, London.

Taylor, J. B. (1993, December). Discretion versus policy rules in practice. In Carnegie-Rochester conference series on public policy (Vol. 39, pp. 195214). North-Holland.

Thurmaier, K. M., \& Willoughby, K. G. (2001). Policy and Politics in State Budgeting. ME Sharpe.

Yandra, A. (2012). Partisipasi Masyarakat dalam Perumusan RPJMD Kota Pekanbaru 2012-2017. Jurnal Publika, 2(1). 